\title{
Axonal Transport of Monoclonal Antibodies
}

\author{
T. C. Ritchie, ${ }^{\star}$ R. H. Fabian, $\dagger$ J. V. A. Choate, ${ }^{\star}$ and J. D. Coulter ${ }^{*} \neq, 1$ \\ *Marine Biomedical Institute and + Departments of Physiology and Biophysics, †Neurology, and \\ $\$$ Psychiatry and Behavioral Sciences, University of Texas Medical Branch, Galveston, Texas 77550
}

Three monoclonal antibodies against rat brain synaptosomes, produced by conventional hybridoma techniques, were screened for their ability to undergo uptake and axonal transport in vivo. Injections of ascitic fluid or of purified immunoglobulin G (IgG) were made into the vitreal chamber of the eye in anesthetized rats to test for anterograde transport in retinal afferents to the contralateral superior colliculus. Retrograde transport by facial nucleus motoneurons was evaluated after injections of antibody into the mystatial vibrissal skin and musculature. Transported immunoglobulins were localized in tissue sections using a modification of the peroxidase-antiperoxidase technique. One monoclonal antibody, S-2C10, was found to undergo anterograde transport in retinal ganglion cells and retrograde axonal transport in facial motoneurons. Transported immunoglobulins were detectable even after injections of dilute antibody solution (0.01-0.05\% IgG), and the uptake-transport process for this antibody appeared saturable. Two other antibodies tested, S-4E9 and S-1G10, exhibited the ability to undergo retrograde transport, but only after injections at relatively high antibody concentrations ( $\geq 1.0 \%$ IgG). Neither of these antibodies was shown to undergo anterograde transport. Following retrograde transport in motoneurons, the $\mathrm{S}-2 \mathrm{C10}$ antibody was localized in neuronal perikarya, proximal dendrites, and the adjacent neuropil of the facial motor nucleus. In contrast, the S-4E9 and S-1G10 antibodies were localized in punctate granules within neuronal cell somata following transport. The findings suggest that the uptake-transport process for the $\mathrm{S}-2 \mathrm{C10}$ antibody is mediated by adsorptive endocytosis following binding of the antibody to a plasma membrane component (or components) present in somadendritic and nerve terminal membranes. Preliminary studies indicate the antigen recognized by $\mathrm{S}-2 \mathrm{C10}$ is likely to be an intrinsic membrane protein or proteoglycan. Uptake of both the S-4E9 and S-1G10 antibodies appears to involve nonspecific, fluid-phase endocytosis. These results indicate that the uptake and axonal transport of monoclonal antibodies will be useful as in vivo and in vitro probes for characterizing neuronal plasma membrane composition and the intracellular processing of macromolecules internalized by these membranes.

Antisera generated against rat brain synaptic membrane and protein fractions contain antibodies that undergo retrograde axonal transport following uptake at nerve terminals (Fabian et al., 1984; Ritchie et al., 1984, 1985b; Wenthold et al., 1984; also R. H. Fabian, T. C. Ritchie, J. V. A. Choate, and J. D.

\footnotetext{
Received June 24, 1985; revised Sept. 6, 1985; accepted Sept. 10, 1985.

The authors wish to thank Paula J. McKinney and Jesus G. Garcia for their excellent technical assistance and Vicki Fagen, Tena Perry, Becky Stumpf, and Mrs. P. Waldrop for typing the manuscript. This research was supported by Grants NS 12481, NS 11255 and NS 07185.

Correspondence should be addressed to Dr. Ritchie, Department of Anatomy University of Iowa, College of Medicine, Iowa City, IA 52242, her current address.

' Present address: Department of Anatomy, University of lowa, College of Medicine, Iowa City, IA 52242

Copyright (c) 1986 Society for Neuroscience $0270-6474 / 86 / 041177-08 \$ 02.00 / 0$
}

Coulter, unpublished observations). The uptake-transport process for antibodies to neural antigens appears to be mediated by binding to nerve membranes, since small amounts of injected antibodies lead to detectable retrograde transport, saturation of the uptake-transport process appears to occur, and the uptaketransport process can be blocked by neutralization of the antibodies with excess antigen (Ritchie et al., 1985b; and R. H. Fabian, T. C. Ritchie, J. V. A. Choate, and J. D. Coulter, unpublished observations). These studies suggested the feasibility of developing specific antibodies to neuronal membrane components as probes for characterizing the neuronal cell surface, and for examining the molecular composition and processing of axonally transported materials.

The goal of the current study was to produce monoclonal antibodies to neuronal membrane components and to evaluate the ability of these antibodies to be taken up and axonally transported in vivo. Somatic cell hybridization methods were used to generate monoclonal antibodies to elements of synaptosomal membranes, and studies of three of the antibodies are presented here. One monoclonal antibody was found to be taken up by adsorptive endocytosis and to undergo both anterograde and retrograde axonal transport. The other two antibodies could not be shown to be transported anterogradely, but some retrograde transport could be demonstrated when large amounts of antibody were injected. The uptake of these latter antibodies is likely to be via nonspecific, fluid-phase endocytosis. Preliminary results of these studies have been reported previously (Ritchie et al., 1985a).

\section{Materials and Methods}

\section{Preparation of synaptosomes and immunization}

Synaptosomes were prepared from rat brains by differential centrifugation according to Gurd et al. (1974). The preparation has been described in detail elsewhere (Ritchie et al., 1985b). The washed synaptosomal pellet was lyophilized, and the protein content was determined by the method of Lowry et al. (1951). Synaptosomes ( $2 \mathrm{mg}$ protein) were suspended in Freund's complete adjuvant $(0.2 \mathrm{ml})$ and distilled $\mathrm{H}_{2} \mathrm{O}(0.2 \mathrm{ml})$ and injected at multiple sites intraperitoneally (ip) and subcutaneously (sc) in 6-week-old female Balb/c mice. Beginning 4 weeks after the initial immunization, the mice were injected (ip and sc) with synaptosomes ( $2 \mathrm{mg}$ protein) suspended in Freund's incomplete adjuvant and distilled $\mathrm{H}_{2} \mathrm{O}$ on each of 3 consecutive days.

\section{Monoclonal antibody production and initial screening}

On the day following the third booster injection, the spleen was removed from an anesthetized, hyperimmunized mouse, and the spleen cells were fused with P3X63 Ag8 myeloma cells according to the method of Kennett et al. $(1978,1980)$ using polyethylene glycol (PEG 1000, KochLight). Hybridomas were selected, and screening for the production of relevant antibodies was begun at $13 \mathrm{~d}$ postfusion.

Culture supernatants were screened for the presence of antibodies against synaptosomal constituents using a dot-immunobinding assay, modified from Hawkes et al. (1982). Synaptosomes were suspended in phosphate buffer (PB $0.1 \mathrm{M}, \mathrm{pH} 7.2$ ) and spotted (1 $\mu \mathrm{g}$ protein/well) 
onto nitrocellulose membranc covering the bottom of Microtitre HA Plates (Millipore). The plates were dried, and after rinsing and blocking (PB containing $0.5 \%$ gelatin and $0.2 \%$ Triton $\mathrm{X}-100$ ), undiluted culture supernatants were applied and incubated 1-2 hr. After additional rinsing and blocking steps, the wells were incubated in goat anti-mouse IgGperoxidase conjugate $(1: 1000)$ for $1 \mathrm{hr}$, rinsed, and incubated with $0.05 \%$ diaminobenzidine (DAB) containing $0.02 \% \mathrm{COCl}_{2}, 0.016 \%$ $\mathrm{NiNH}_{4} \mathrm{SO}_{4}$, and $0.01 \% \mathrm{H}_{2} \mathrm{O}_{2}$ (Adams, 1981). The plates were then rinsed and dried. This procedure results in a deposit of black reaction product on the nitrocellulose membrane of positive wells. The immunoglobulin class of the antibodies was identified by substituting immunoglobulin class-specific, peroxidase-labeled antibodies (e.g., anti-IgM) for goat antimouse IgG in the dot-immunobinding assay.

Twenty-one clones were selected by positive staining for synaptosomes on the dot-immunobinding assay and expanded. This report presents studies on three of the clones (S-2C10, S-4E9, S-1G10), each of which secretes antibodies of the IgG class. Ascitic fluids were produced from these clones by conventional methods in Balb/c mice. All ascitic fluids were tested for synaptosome binding activity at dilutions from $1: 1$ to $1: 128,000$ on the dot-immunobinding assay. The cell line secreting antibody $\mathrm{S}-2 \mathrm{C} 10$ was subcloned twice by limiting dilution and ascites was produced for further testing.

Antibodies (IgG fractions) produced by all three clones were purified from ascitic fluid by chromatography on DEAE Affi-gel blue (Bio-Rad) using a modification of the method of Bruck et al. (1982). With the protocol utilized, some contamination by transferrin occurs, but the IgG fraction is free of albumin and proteases. The fractions corresponding to the IgG peak were pooled, the total protein content was determined, and the solution was dialyzed against $50 \mathrm{~mm}$ phosphate buffer for 24 $48 \mathrm{hr}$ at $4^{\circ} \mathrm{C}$ prior to lyophilization for storage.

\section{Screening antibodies for axonal transport}

Ascitic fluid, or the purified IgG fraction, produced by the three clonesS-2C10, S-4E9, and S-1G10-were evaluated for the presence of antibodies that undergo anterograde or retrograde axonal transport. For screening in rats, injections of ascitic fluid or dilute IgG $(10 \mu \mathrm{l})$ were made in to the vitreal chamber of the eye to test for anterograde axonal transport in the retinal ganglion cell projections to the superior colliculus. Injections of ascitic fluid or $\mathrm{IgG}$ ( $50 \mu \mathrm{l}$ total volume) were also made at multiple sites into the facial vibrissal skin and underlying musculaturc to examine retrograde transport in facial nucleus motoneurons and transganglionic transport in trigeminal afferent projections to the spinal trigeminal complex. Injections were restricted to one side of each rat, and the contralateral side served as control.

After survival times of 4-72 $\mathrm{hr}$, the rats were anesthetized and perfused with saline followed by $3.5 \%$ paraformaldehyde in PB, then $30 \%$ sucrose. Transported mouse immunoglobulins were localized in frozen sections with a modification of the peroxidase-antiperoxidase (PAP) method of Sternberger (1978), by the procedure detailed previously (Ritchie et al., 1985b), using goat anti-mouse IgG (heavy and light chains specific, without cross-reactivity to rat immunoglobulin; Cappel) and mouse PAP (Sternberger-Meyer). The species-specific anti-mouse IgG was used successfully to abolish the "spurious" staining that often occurs when staining rat tissue to localize mouse antibodics (Houser et al., 1984; see Fig. $2 F$ ). The specific staining for mouse IgG was amplified by sequentially repeating the incubation steps in anti-mouse $\mathrm{IgG}$ and mouse PAP prior to the peroxidase reaction (Lansdorp et al., 1984). In all cases the peroxidase reaction was carried out as described above.

In order to study the effect of antibody concentration on antibody transport, the purified antibodies (IgG fractions) were diluted with $\mathrm{H}_{2} \mathrm{O}$ to concentrations ranging from 0.01 to $5.0 \%(\mathrm{wt} / \mathrm{vol})$ and injected into rats as described above. It was assumed in preparing the antibody solutions that all of the protein in the lyophilized samples (see above) was active monoclonal IgG. The absolute concentration of active antibody was likely somewhat less, but care was taken to standardize the purification procedure to facilitate comparisons between the different antibodies at the concentrations utilized. The total volumes injected were always $50 \mu \mathrm{l}$ for the vibrissal injections and $10 \mu \mathrm{l}$ for the cyc injections. After survival periods of $30-36 \mathrm{hr}$, the rats were perfused, and frozen sections were stained for mouse immunoglobulin with two sequential incubations in the species-specific link antiserum and PAP prior to the peroxidase reaction. The intensity of staining in the superior colliculus and both the intensity of staining and the numbers of labeled neurons in the facial nucleus were compared in at least two animals for each antibody concentration.

\section{Immunocytochemical localization of antigens}

The three monoclonal antibodies were used to stain rat brain sections with the PAP immunocytochemical procedure. Particular emphasis was placed on the distribution of labeling in the facial motor nucleus, the spinal trigeminal nucleus and tract, and the superficial laminae of the superior colliculus for correlations with the axonal transport of the antibodies in these systems. Rats were perfused as described, and frozen sections of the brain were cut in the transverse plane. Sections were incubated overnight in ascitic fluid diluted to $1: 10,000$ to $1: 100,000$. The immunocytochemical staining was completed utilizing the procedure and reagents described above. The specificity of the staining was indicated by the decrease in staining density that occurred with increasing dilutions of the monoclonal antibodies. Additional controls consisted of omitting the monoclonal antibodies from the overnight incubation solution or of substituting $\mathrm{P} 3 \times 63 \mathrm{Ag} 8$ culture supernatant (diluted 1:10) for the monoclonal ascites in this step. The control sections were reacted simultaneously with the sections stained with the monoclonal antibodies. No staining was observed on the control sections.

\section{Preliminary antigen characterization}

Initial experiments to identify the synaptosomal components recognized by the antibodies utilized electrophoresis and Western immunoblotting of synaptosomal proteins. Dot-immunobinding assays of detergent-solubilized and lipid-extracted synaptosomes werc also performed.

For electrophoresis (Laemmli, 1970), lyophilized samples of synaptosomes were dissolved in treatment buffer: $1.0 \%$ SDS, $1.0 \%$ mercaptoethanol in $50 \mathrm{~mm} \mathrm{~PB} \mathrm{(pH} \mathrm{7.2),} \mathrm{heated} \mathrm{at} 100^{\circ} \mathrm{C}$ for $5 \mathrm{~min}$ and applied to $10 \%$ polyacrylamide gels. After electrophoresis, proteins were electrophoretically transferred to nitrocellulose paper (Towbin et al., 1979). Western blots were immunocytochemically stained with culture supernatants produced by S-2C10, S-4E9, and S-1G10 (diluted 1:10), or with ascitic fluids (diluted 1:100-1:1000) from the three hybridoma cell lines. The blots were incubated in $0.5 \%$ Triton X-100, $1.5 \%$ gelatin in PBS for $30 \mathrm{~min}$, washed briefly, and incubated in the primary antibodies for $1 \mathrm{hr}$ with agitation. After thorough washing with $0.1 \%$ Triton $\mathrm{X}-100$ PBS, the blots were incubated in 1:1000 goat anti-mouse IgG-peroxidase conjugate (Cappel) in $0.1 \%$ Triton X-100 PBS. The blots were then washed and the peroxidase reaction was carricd out as described abovc.

The S-2C10 antibody did not exhibit binding to the denatured and reduced synaptosomal proteins on the immunoblots, so the ability of $\mathrm{S}-2 \mathrm{C} 10$ to bind to various treated synaptosomal fractions was determined by dot-immunobinding assay. Lyophilized synaptosomes were solubilized with nonionic (Triton X-100), zwitterionic (CHAPS), and ionic (SDS, deoxycholate) detergents $(0.5-2.0 \%$ detergent solutions in $50 \mathrm{~mm}$ Tris buffer, $\mathrm{pH} \mathrm{7.2)} \mathrm{with} \mathrm{stirring} \mathrm{for} 4-48 \mathrm{hr}$ at $4^{\circ} \mathrm{C}$. The suspensions were then centrifuged at $100,000 \times g$ for $1 \mathrm{hr}$, and both pellets and supernatants were collected and analyzed on the immunodot system for binding activity. Lyophilized synaptosomes were also repeatedly extracted with chloroform and methanol as described by Gombos and Zanetta (1977). The protein content of each fraction was determined (Lowry et al., 1951) prior to the application of $1 \mu \mathrm{g}$ protein/well onto the nitroccllulose membranc of the microtiter plates. The wells were incubated with S-2C10 ascites, or with ascites produced by the other clones, at dilutions ranging from 1:100-1:300,000, and stained with the protocol described above.

\section{Results}

\section{Axonal transport}

As shown in Figure 1, monoclonal antibody S-2C10 was anterogradely transported by retinal ganglion cells. Immunocytochemical staining for the presence of transported mouse immunoglobulin demonstrated intense staining in the superficial layers of the superior colliculus contralateral to the injected eye, while no staining was present on the control side (Fig. 1, $A$ and $B$ ). At the light microscope, it was not possible to localize the transported antibody to specific neuronal elements (Fig. $1 B$ ), although staining for the antibody presumably included the nerve endings of the retinotectal afferents that terminate in the superficial tectal layers (Drager and Hubel, 1976; Kanaseki and Sprague, 1974). 

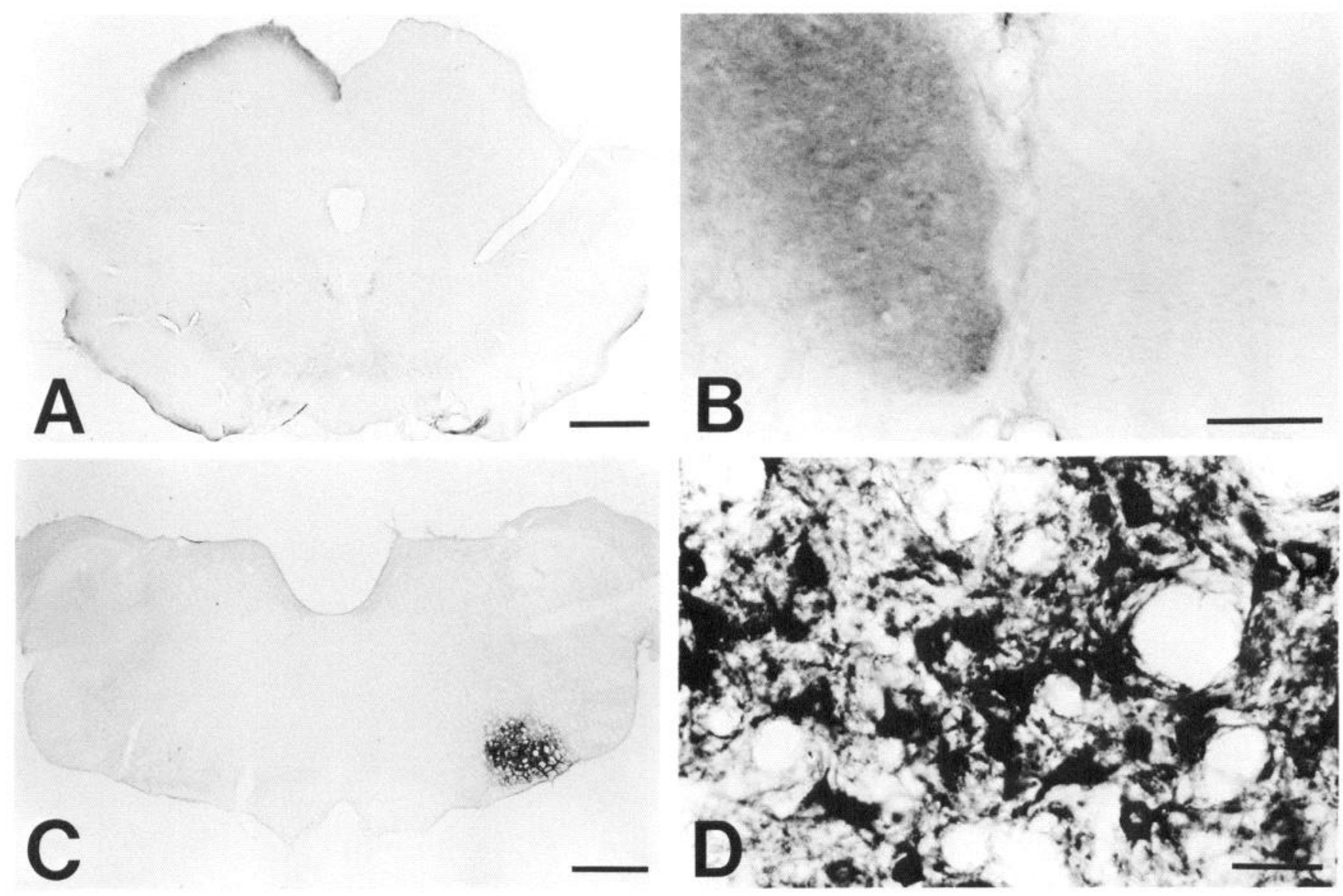

Figure 1. Monoclonal antibody S-2C10 localized with immunocytochemistry following anterograde axonal transport in retinal ganglion cells and retrograde transport in facial motoneurons. The survival period was $2 \mathrm{~d}$. $A$, Anterogradely transported $\mathrm{S}-2 \mathrm{C} 10$ in the retinorecipient laminae of the superior colliculus contralateral to the injected eye. $B$, Higher magnification of the medial superior colliculi. $C$, Retrogradely transported S$2 \mathrm{C} 10$ antibody in motoneurons and neuropil of the facial motor nucleus, ipsilateral to the injected vibrissal musculature. $D$, Higher magnification of $C$ showing individually labeled motoneurons and stained neuropil. Calibration: $A$ and $C, 1.0 \mathrm{~mm} ; B$ and $D, 100 \mu \mathrm{m}$.

Anterogradely transported $\mathrm{S}-2 \mathrm{C} 10$ antibody was first detectable in the superior colliculus $6 \mathrm{hr}$ after injection, giving an estimated maximum transport velocity of $100 \mathrm{~mm} / \mathrm{d}$, which includes the time for uptake and processing of the antibody by the retinal ganglion cells prior to axonal transport. Varying the postinjection survival period from 24 to $72 \mathrm{hr}$ resulted in little change in the intensity or appearance of staining for the transported antibody in the superior colliculus. Longer time intervals were not examined.

Injections of the $\mathrm{S}-2 \mathrm{C} 10$ antibody into the eye also produced detectable anterograde transport to other areas that receive retinal projections, including the dorsal lateral geniculate nucleus and the pretectal area. Occasionally, retrogradely transported immunoglobulins were evident in the oculomotor nucleus ipsilateral to the injected eye. This labeling was most likely due to leakage of the injected antibody from the eye to nerve endings innervating the extraocular muscles.

Injections of $\mathrm{S}-2 \mathrm{C} 10$ ascites into the vibrissal musculature resulted in retrograde axonal transport to ipsilateral facial nucleus motoneurons (Fig. 1). Punctate as well as diffuse cytoplasmic staining occurred in motoneuron cell bodies and proximal dendrites. In addition, there was intense staining of the surrounding neuropil of the facial motor nucleus (Fig. 1, $C$ and $D$ ). The reaction product in the neuropil of the facial nucleus could not be localized to specific elements, but may be located in fine dendritic branches of the labeled motoneurons. Alternatively, this staining may reflect the presence of immunoglobulins in elements other than the motoneurons in which the antibody was originally transported, i.e., some of the antibody may have diffused or been transferred out of the motoneurons subsequent to retrograde transport.

In some cases, a small number of retrogradely labeled motoneurons were present in the contralateral facial nucleus. These cells were always located at the medial edge of the lateral division of the nucleus. In addition, retrogradely labeled motoneurons were sometimes observed in the trigeminal motor nucleus on the injected side, indicating involvement of the masseter muscles in some injections. The vibrissal injections of $\mathrm{S}-2 \mathrm{C} 10$ ascites did not, however, produce detectable labeling in the spinal trigeminal complex, indicating that transganglionic transport by trigeminal afferents did not occur in any appreciable amount.

Axonal transport of the other two antibodies, S-4E9 and $\mathrm{S}-1 \mathrm{G} 10$, could not be demonstrated in the anterograde direction following intraocular injections. Retrograde transport in facial motoneurons, however, could be obtained, but only when large amounts of these antibodies were injected (see below) or when other measures were used to maximize detection. In the latter instance, rats received injections of these antibodies ( $\geq 1 \% \mathrm{IgG})$ into the vibrissal musculature on each of two successive days. The next day, the animals were perfused and sections were stained with repeated incubations of goat anti-mouse IgG antibody and PAP prior to the peroxidase reaction. These measures led to just-detectable staining in the soma and proximal dendrites of some facial nucleus motoneurons (Fig. 3, D and $E)$. The staining was largely punctate within the cell cytoplasm, 

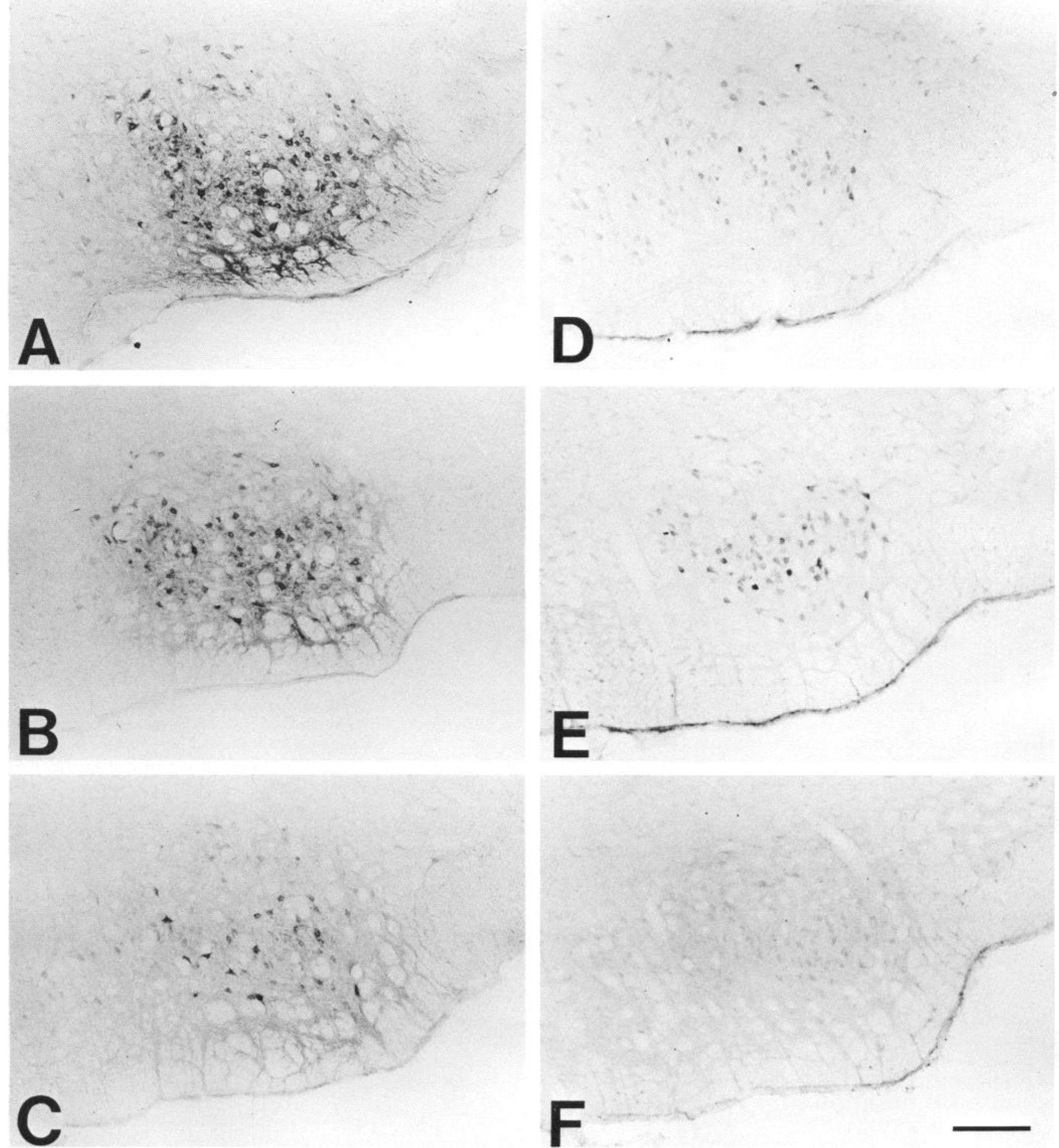

Figure 2. Retrogradely transported antibodies in the facial nucleus, 30-36 hr after injections of purified monoclonal IgGs at different concentrations into the vibrissal musculature. $A, 1.0 \%$ solution of $\mathrm{S}-2 \mathrm{C} 10 \mathrm{IgG} ; B, 0.1 \%$ solution of $\mathrm{S}-2 \mathrm{C} 10 \mathrm{IgG} ; C, 0.05 \%$ solution of S-2C10 IgG; $D, 1.0 \%$ solution of S-4E9 IgG; $E, 1.0 \%$ solution of $\mathrm{S}-1 \mathrm{G} 10 \mathrm{IgG} ; F$, facial nucleus ipsilateral to the control, noninjected side after immunocytochemical staining. Calibration, $250 \mu \mathrm{m}$.

only a few neurons showed any staining, and no staining was present in the neuropil of the facial nucleus. Both of these antibodies produced this pattern of staining following transport under these conditions. No evidence of transganglionic transport in trigeminal afferents was obtained.

Antibody concentrations and axonal transport

Antibodies (purified IgG fraction) were injected at concentrations varying from 0.01 to $5.0 \%$ to determine the lowest con- centrations at which axonal transport could be detected and to examine the appearance and relative intensity of staining with injections of higher antibody concentrations.

Following intraocular injections of S-2C10 IgG, anterograde transport to the superior colliculus could first be detected at antibody concentrations of $0.05 \%$. As the concentration of the injected antibody increased, the density of staining for the transported antibody increased until antibody concentrations reached the range of $0.1-0.5 \%$. Higher concentrations, from 1 to $5 \%$, 

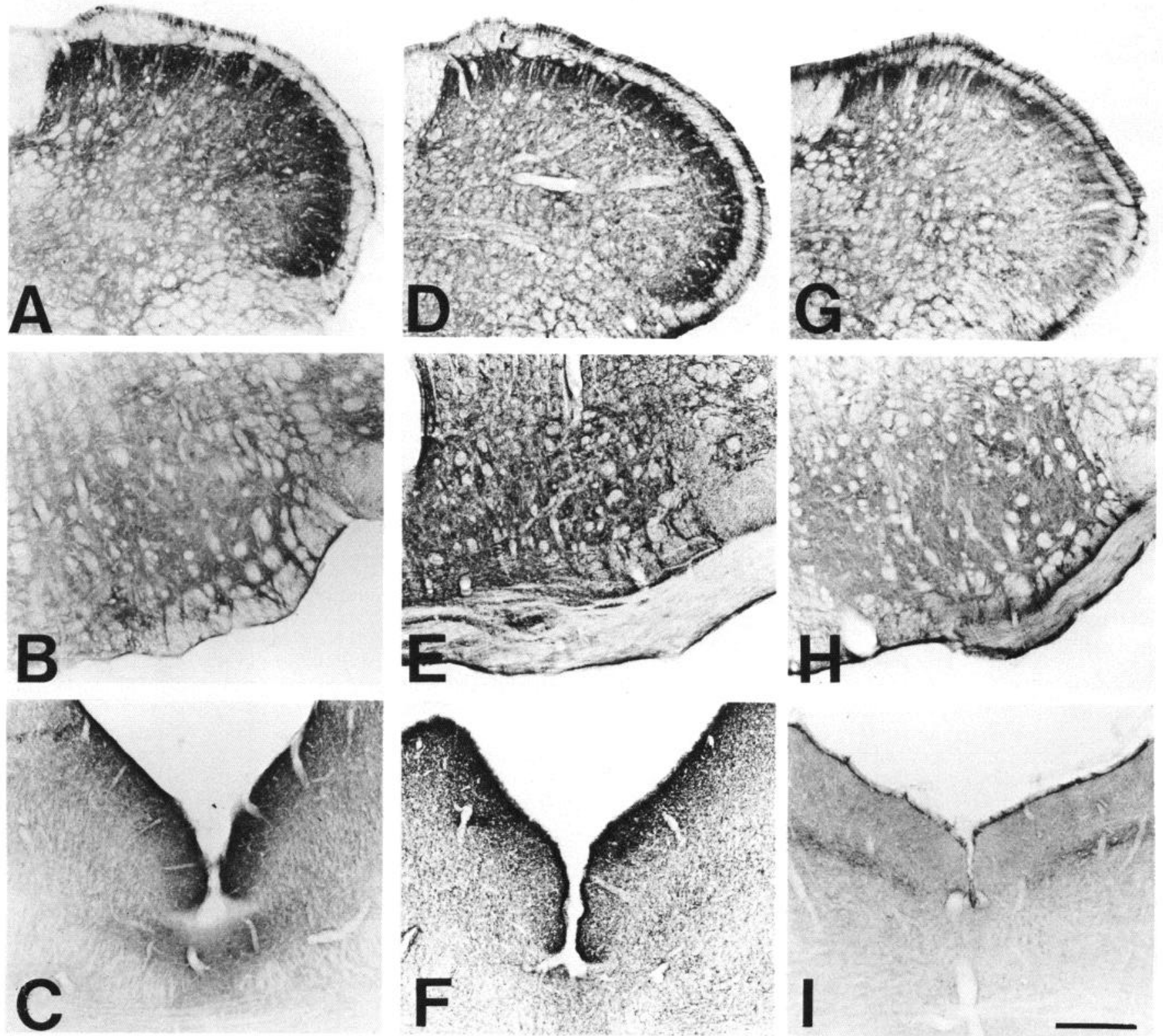

Figure 3. Immunocytochemical staining of rat brain sections with monoclonal antibodies S-2C10 $(A-C)$, S-4E $(D-F)$, and S-1G10 $(G-I)$. The spinal trigeminal complex is illustrated in $A, D$, and $G$; the facial motor nucleus in $B, E, H$; and the medial portion of the superior colliculi in $C$, $F$, and $I$. Calibration, $300 \mu \mathrm{m}$.

produced little detectable increase in staining intensity and did not alter the appearance of the staining for the transported antibody. As noted previously, neither the S-4E9 nor the S-1G10 antibodies could be determined to undergo anterograde transport following intraocular injections, even at concentrations exceeding $1 \%$ IgG.

Following injections of the $\mathrm{S}-2 \mathrm{C} 10$ antibody into the vibrissal musculature, retrograde axonal transport of the antibody could be detected at concentrations as low as $0.01 \% \mathrm{IgG}$. As shown in Figure 2, raising the concentration of the injected antibody in the range between 0.05 to $0.1 \%$ resulted in an increase in the number of facial motoneurons that contained the transported antibody, as well as producing more intense staining in the facial nucleus. Increasing the concentrations of injected antibody beyond $0.5-1.0 \%$ concentrations, however, resulted in little, if any, change in the number of facial motoneurons labeled or the intensity of staining.

In contrast, the retrograde axonal transport of the S-4E9 and
S-1G10 antibodies was difficult to detect unless they were injected at concentrations at or above $1.0 \%$ IgG (Fig. 2, $D$ and $E)$. Even at these higher concentrations, some of the motoneurons failed to show the presence of transported antibody and the staining intensity was light.

\section{Immunocytochemical staining}

Immunocytochemical staining of rat brain sections using the S-2C10 antibody revealed staining of gray matter that was particularly dense in zones of high nerve-terminal density. This includes the superficial laminae of the spinal trigeminal nucleus (Fig. $3 \mathrm{~A}$ ) and the superficial laminae of the superior colliculus (Fig. $3 C$ ). Neuronal cell bodies were not stained in most regions, but appeared as clear areas surrounded by stained elements. However, some large neurons, such as facial motoneurons (Fig. $3 B$ ), did exhibit light cytoplasmic staining. The white matter, myelinated axons and fiber tracts, did not exhibit staining.

The immunocytochemical staining with S-4E9 (Fig. 3, D-F) 
and S-1G10 (Fig. 3, $G-I$ ) indicated that both of these antibodies, unlike $\mathrm{S}-2 \mathrm{C} 10$, stained both gray and white matter. As noted for S-2C10, both S-4E9 and S-1G10 stained most intensely brain regions of high terminal density. S-4E9 produced granular labeling of presumptive nerve terminals and staining of axoplasm in fiber tracts. Scattered populations of neuronal cell bodies exhibited punctate staining in the perinuclear cytoplasm. S-1G10 produced diffuse staining of neuronal cytoplasm, as well as the axoplasm of selected fiber tracts.

\section{Initial characterization of antigens}

Immunochemical staining of Western blots of synaptosomal proteins separated on SDS-PAGE produced no staining by S-2C10, while S-1G10 and S-4E9 exhibited binding to bands with electrophoretic mobilities corresponding to 32 and $24 \mathrm{kDa}$, respectively.

Analysis of the binding of $\mathrm{S}-2 \mathrm{Cl} 0$ to various detergent-solubilized fractions of synaptosomes on the dot-immunobinding assay indicated no binding of $\mathrm{S}-2 \mathrm{C} 10$ to any of the detergentsolubilized fractions. In preparations solubilized with various detergents (Triton X-100, CHAPS, deoxycholate), binding of the antibody was associated with the detergent-insoluble fractions. Exposure to SDS, however, abolished the ability of S-2C10 to bind to either the soluble or insoluble fractions, suggesting that the epitope may be destroyed by the denaturing conditions with this detergent. Delipidization of synaptosomes with repeated extractions with chloroform-methanol did not diminish the binding of S-2C10 to the synaptosomal membranes, indicating that the antigen is unlikely to be a lipid.

\section{Discussion}

The results of these studies indicate that the uptake and axonal transport of monoclonal antibody S-2C10 is likely to be mediatcd by spccific binding of the antibody to neuronal plasma membranes. Injections of as little as $0.01 \% \mathrm{IgG}(50-100 \mathrm{pmol})$ led to detectable transport, and the uptake-transport process appeared saturable, since increasing amounts of injected antibody beyond the range of $0.5-1.0 \%$ produced little increase in the amount transported. In contrast, detection of retrograde transport of the S-4E9 and S-1G10 antibodies required substantially higher concentrations of injected antibody and saturation of the uptake transport process could not be demonstrated. The uptake mechanism for $\mathrm{S}-2 \mathrm{C} 10$ thus resembles that of other macromolecules, both endogenous (NGF) and exogenous (antibodies to dopamine- $\beta$-hydroxylase, cholera and tetanus toxins, lectins), that are internalized by adsorptive or "receptor"-mediated endocytosis after binding to components of the cell surface (Dumas et al., 1979; Fillenz et al., 1976; Gonatas et al., 1979; Grafstein and Forman, 1980; Kristensson, 1978; Schwab et al., 1978; Schwab and Thoenen, 1978, 1982; Silverstein et al., 1977; Steinman et al., 1983; Thoenen and Barde, 1980; Trojanowski, 1983; van Heyningen, 1974; Wan et al., 1982; Ziegler et al., 1976). Uptake of these substances depends on the number, affinity, rate of turnover, and function of the cell-surface binding sites (Schwab and Thoenen, 1982; Silverstein et al., 1977; Steinman et al., 1983). The process is selective in that specific receptors mediate the uptake of specific ligands, and the mechanism has a defined capacity and is, therefore, saturable (Dumas et al., 1979). Although the process of receptormediated endocytosis, in the strict sense, refers to the uptake of naturally occurring endogenous ligands, the adsorptive uptake of exogenous molecules, including antibodies, which bind to neuronal membranes should mimic most aspects of the natural process. To the extent examined here, the uptake-transport of antibody $\mathrm{S}-2 \mathrm{C} 10$ appears to conform to this model.

In contrast, the uptake of the other two antibodies, S-4E9 and S-1G10, appears to be mediated by fluid-phase endocytosis, a nonspecific process dependent on the extracellular concentra- tion of the ligand (Kristensson, 1978; Silverstein et al., 1977; Steinman et al., 1983). Many macromolecules (e.g., HRP, serum albumin, native ferritin), which do not bind or bind only weakly to membranes, gain entry into cells by this means. Antibodies without accessible surface membrane binding sites would presumably fall into this category. Although S-4E9 and S-1G10 exhibited binding to synaptosomal components on Western immunoblots, the epitopes may not be accessible on the cell surface for binding the antibodies in vivo. The alternative, which cannot be ruled out at the present time, is that the S-4E9 and S-1G10 antibodies may bind to accessible synaptosomal membrane components with low affinity or that the sites themselves are few in number and/or turn over slowly on the surface membrane.

Since the S-2C10 antibody readily undergoes both anteroand retrograde axonal transport, the surface membrane component to which it presumably binds to gain entry to the cell is present on both somato-dendritic and nerve terminal plasma membranes. Major constituents of these membranes include various glycoproteins, glycolipids, and other complex carbohydrate-containing macromolecules (Gombos and Zanetta, 1977; Gurd, 1977; Kelly, 1984; Mahler, 1979; Margolis and Margolis, 1979). To date, it has not been possible to identify the antigen recognized by the S-2C10 antibody. It seems unlikely to be a glycolipid or to be among the major classes of glycosaminoglycans, as most of these are readily solubilized by the treatments employed for the immunobinding assays used here (Margolis and Margolis, 1979). As noted, the antigen recognized by the S-2C10 antibody remains associated with the insoluble fraction of synaptosomal membranes following organic solvent (chloroform-methanol) extraction or treatment with various nonionic or zwitterionic detergents. SDS treatment, on the other hand, which denatures proteins, appears to destroy the epitope recognized by the antibody, since neither the soluble nor insoluble fractions bind the antibody after SDS exposure. Based on these initial observations, the antigen recognized by the S$2 \mathrm{C} 10$ antibody is likely to be an integral membrane protein or possibly a proteoglycan.

The antigen to which $\mathrm{S}-2 \mathrm{ClO}$ antibody binds is apparently synthesized and axonally transported both retrogradely and anterogradely in peripheral nerves (Ritchie et al., 1985a). Immunocytochemical staining of peripheral nerves using the S-2C10 antibody reveals light staining of individual fibers in normal nerves. When the nerves are ligated to block axonal flow, however, very intense staining appears proximal to the ligation, and to a lesser extent distally. These recent studies are consistent with the findings regarding transport of the antibody in both the antero- and retrograde directions.

Immunocytochemistry in rat brain revealed widespread distributions of staining for each of the three antibodies. Although differences in the staining patterns were noted, it was not possible to correlate the immunocytochemical staining with the ability of the different antibodies to undergo axonal transport in the test systems utilized. Immunoreactivity for S-2C10, S-4E9, and S-1G10 was evident in the retinorecipient laminae of the superior colliculus, as well as in the motoneurons and neuropil of the facial nucleus; this finding is consistent with each of the antigens being synthesized by retinal ganglion cells and facial motoneurons. However, examination of the ganglion cell somadendritic membranes and motoneuron terminals at the electronmicroscopic level will be required to localize the antigens in the membranes at the uptake sites.

The S-2C10 antibody may have been released by the facial motoneurons after retrograde transport to the cell bodies in the facial nucleus, i.e., the antibody may have undergone retrograde transcellular transport. This phenomenon has been previously documented for both tetanus toxin (Price et al., 1975; Schwab and Thoenen, 1976; Schwab et al., 1979) and a wheat germ 
agglutinin (WGA) HRP conjugate (Harrison et al., 1984). Immunocytochemical staining to localize S-2C10 antibody after retrograde transport in facial motoneurons resulted in staining within motoneurons, as well as the surrounding neuropil of the facial nucleus. A similar pattern of staining was noted previously after retrograde transport of antibodies in a polyclonal antiserum made against synaptosomes (Ritchie et al., 1985b). At the light-microscopic level it has not been possible to determine, in either case, whether the transported antibodies are located within fine dendritic processes of the motoneurons or have been transferred transcellularly. Regardless of whether ultrastructural analysis reveals that the $\mathrm{S}-2 \mathrm{C} 10$ antibody is transferred transcellularly, this pattern of neuropil labeling is distinctly different from that seen after retrograde transport of other macromolecules, such as various lectins, HRP (Borges and Sidman, 1982; Gonatas et al., 1977, 1979; LaVail and LaVail, 1974; Schwab and Thoenen, 1982), or the other antibodies studied here. This differential localization of the S-2C10 antibody subsequent to retrograde transport presumably reflects a unique mode of intracellular processing of the antibody, compared to other macromolecules transported by nerve cells.

It is of interest that the S-2C10 antibody undergoes fast anterograde axonal transport in retinal ganglion cells. Other antibodies that have been studied, including both monoclonal and polyclonal antibodies (Ritchie et al., 1985b; and R. H. Fabian, T. C. Ritchie, J. V. A. Choate, and J. D. Coulter, unpublished observations) have not exhibited anterograde axonal transport. Other exogenous proteins that have been demonstrated to undergo anterograde transport after intravitreal injections are HRP, the lectin WGA, and three mannose binding lectins (Fabian and Coulter, 1985; Hansson, 1973; Itaya and Van Hoesen, 1982; Margolis and LaVail, 1981, 1984; Mesulam and Mufson, 1980; Ruda and Coulter, 1982). It is notable that the anterograde transport velocity of the S-2C10 antibody (approximately 100 $\mathrm{mm} / \mathrm{d}$ ) is $3-4 \times$ faster than the anterograde transport of WGA lectin from the eye $(22-44 \mathrm{~mm} / \mathrm{d})$, although it is comparable to that of HRP $(120 \mathrm{~mm} / \mathrm{d})$. The fast axonal transport of the antibody would be consistent with the antibody being transported in association with newly synthesized protcins destincd for the plasma membrane. Many of the constituents of nerve terminal membranes (glycoproteins and other glycoconjugate macromolecules) are considered to be transported at the fastest rates (100-400 mm/d) (Hoffman and Lasek, 1980; Karlsson, 1980; Willard et al., 1974; see Grafstein and Forman, 1980).

The results of the current study, as well as previous studies of the axonal transport of polyclonal antibodies (Ritchie et al., 1985b; and R. H. Fabian, T. C. Ritchie, J. V. A. Choate, and J. D. Coulter, unpublished observations), indicate that the uptake and intracellular processing of antibodies may differ from that of other ligands that are taken up and transported by nerve cells. It also appears that antibodies directed at different classes of membrane antigens may be processed differently within neurons. So far, this has only been documented by observing differences in the immunocytochemical staining patterns for different antibodies subsequent to their transport. Presumably, differences in the transport and processing of different antibodies reflect differences in the intracellular processing of their respective membrane antigens. This assumes that the antibody and antigen are processed conjointly. However, the characteristics of antibody transport and processing compared to that of their homologous antigens are in need of investigation. Transport and processing of an antibody may not reflect that of its corresponding antigen, since the antibody could alter normal processing of the antigen. Alternatively, the antibody and antigen could be dissociated within the cell with the antibody being processed independently. Ultrastructural analysis of the subcellular mechanisms involved in the in vivo processing of the antibody, compared to corresponding analyses of antigen pro- cessing, using the antibody for immunocytochemistry, should be helpful in resolving these questions.

\section{References}

Adams, J. C. (1981) Heavy metal intensification of DAB-based HRP reaction product. J. Histochem. Cytochem. 29: 775-780.

Borges, L. F., and R. L. Sidman (1982) Axonal transport of lectins in the peripheral nervous system. J. Neurosci. 2: 647-653.

Bruck, C., D. Portelle, C. Glineur, and A. Bollen (1982) One-step purification of mouse monoclonal antibodies from ascitic fluid by DEAE affigel blue chromatography. J. Immunol. Methods 53: 313319.

Drager, U. C., and D. H. Hubel (1976) Topography of visual and somatosensory projections to the mouse superior colliculus. J. Neurophysiol. 39: 90-101.

Dumas, M., M. E. Schwab, and H. Thoenen (1979) Retrograde axonal transport of specific macromolecules as a tool for characterizing nerve terminal membranes. J. Neurobiol. 10: 179-197.

Fabian, R. H., and J. D. Coulter (1985) Transneuronal transport of lectins. Brain Res. 344: 41-48.

Fabian, R. H., T. C. Ritchie, and J. D. Coulter (1984) Properties of axonally transported antibodies to rat brain membrane fractions. Neurosci. Abstr. 10: 353.

Fillenz, M., C. Gagnon, K. Stöckel, and H. Thoenen (1976) Selective uptake and retrograde axonal transport of dopamine- $\beta$-hydroxylase antibodies in peripheral adrenergic neurons. Brain Res. 114: 293303.

Gombos, G., and J. P. Zanetta (1977) Recent methods for the separation and analysis of central nervous system glycoproteins. Res. Methods. Neurochem. 4: 307-363.

Gonatas, N. K., S. U. Kim, A. Steiber, and S. Avrameas (1977) Internalization of lectins in neuronal GERL. J. Cell Biol. 73: 1-13.

Gonatas, N. K., C. Harper, T. Mizutani, and J. O. Gonatas (1979) Superior sensitivity of conjugates of horseradish peroxidase with wheat germ agglutinin for studies of retrograde axonal transport. J. Histochem. Cytochem. 27: 728-734.

Grafstein, B., and D. S. Forman (1980) Intracellular transport in neurons. Physiol. Rev. 60: 1167-1283.

Gurd, J. W. (1977) Identification of lectin receptors associated with rat brain postsynaptic densities. Brain Res. 126: 154-159.

Gurd, J. W., L. R. Jones, H. R. Mahler, and W. J. Moore (1974) Isolation and partial characterization of rat brain synaptic plasma membranes. J. Neurochem. 22: 281-290.

Hansson, H.-A. (1973) Uptake and intracellular bidirectional transport of horseradish peroxidase in retinal ganglion cells. Exp. Eye Res. 16: 377-388.

Harrison, P. I., H. Hultborn, E. Jankowska, R. Katz, B. Storai, and D. Zytnicki (1984) Labelling of interneurons by retrograde transynaptic transport of horseradish peroxidase from motoneurons in rats and cats. Neurosci. Lett. 45: 15-19.

Hawkes, R., E. Niday, and J. Gordon (1982) A dot-immunobinding assay for monoclonal and other antibodies. Anal. Biochem. 119:142147.

Hoffman, P. N., and R. J. Lasek (1980) Axonal transport of the cytoskeleton in regenerating motor neurons: Constancy and change. Brain Res. 202: 317-333.

Houser, C. R., R. P. Barber, G. D. Crawford, D. A. Matthews, P. E. Phelps, P. M. Salvaterra, and J. E. Vaughn (1984) Species-specific second antibodies reduce spurious staining in immunocytochemistry. J. Histochem. Cytochem. 32: 395-402.

Itaya, S. K., and G. W. Van Hoesen (1982) WGA-HRP as a transneuronal marker in the visual pathways of monkey and rat. Brain Res. 236: 199-204.

Kanaseki, T., and J. M. Sprague (1974) Anatomical organization of pretectal nuclei and tectal laminae in the cat. J. Comp. Neurol. 158: 319-338.

Karlsson, J. O. (1980) Proteins of rapid transport: Polypeptides interacting with the lectin from lens culinaris. J. Neurochem. 34: 11841190.

Kelly, D. T. (1984) Nervous system glycoproteins: Molecular properties and possible function. In The Biology of Glycoproteins, R. J. Ivatt, ed., pp. 323-368, Plenum, New York.

Kennett, R. H., J. Denis, A. Tung, and N. Klinman (1978) Hybrid plasmacytoma production: Fusions with adult spleen cells, mono- 
clonal spleen fragments, neonatal spleen cells, and human spleen cells. Curr. Top. Microbiol. Immunol. 81: 77-91.

Kennett, R. H., T. J. McKearn, and K. B. Bechtol, eds. (1980) Monoclonal Antibodies, Hybridomas: A New Dimension in Biological Analysis, p. 423, Plenum, New York.

Kristensson, K. (1978) Retrograde transport of macromolecules in axons. Annu. Rcv. Pharmacol. Toxicol. 18: 97-110.

Laemmli, U. K. (1970) Cleavage of structural protein during the assembly of the head of bacteriophage T4. Nature 226: 680-685.

Lansdorp, P. M., T. H. van der Kwast, M. DeBoer, and W. P. Zeijlemaker (1984) Step-wise amplified immunoperoxidase (PAP) staining. I. Cellular morphology in relation to membrane markers. J. Histochem. Cytochem. 32: 172-178.

LaVail, J. H., and M. M. LaVail (1974) The retrograde intraxonal transport of horseradish peroxidase in the chick visual system: A light and electron microscopic study. J. Comp. Neurol. 157: 303-357.

Lowry, O. H., N. J. Rosebrough, A. L. Farr, and R. J. Randall (1951) Protein measurement with the folin phenol reagent. J. Biol. Chem. 193: 265-275.

Mahler, H. R. (1979) Glycoproteins of the synapse. In Complex Carbohydrates of Nervous Tissue, R. U. Margolis and R. K. Margolis, eds., pp. 165-184, Plenum, New York.

Margolis, T. P., and J. H. LaVail (1981) Rate of anterograde axonal transport of $\left[{ }^{125} \mathrm{I}\right]$ wheat germ agglutinin from retina to optic tectum in the chick. Brain Res. 229: 218-223.

Margolis, T. P., and J. H. LaVail (1984) Further evidence in support of the selective uptake and anterograde transport of [ $\left.{ }^{125} \mathrm{I}\right]$ wheat germ agglutinin by chick retinal ganglion cells. Brain Res. 324: 21-28.

Margolis, R. U., and R. K. Margolis (1979) Structure and distribution of glycoproteins and glycosaminoglycans. In Complex Carbohydrates of Nervous Tissue, R. U. Margolis and R. K. Margolis, eds., pp. 4573, Plenum, New York.

Mesulam, M.-M., and E. J. Mufson (1980) The rapid anterograde transport of horseradish peroxidase. Neuroscience 5: 1277-1286.

Price, D. L., J. Griffin, A. Young, K. Peck, and A. Stocks (1975) Tetanus toxin: Direct evidence for retrograde intraaxonal transport. Science 188: 945-947.

Ritchie, T. C., R. H. Fabian, P. J. McKinney, and J. D. Coulter (1984) Axonal transport of antibodies to membrane fractions of rat brain. Neurosci. Abstr. 10: 355.

Ritchie, T. C., R. H. Fabian, J. V. A. Choate, and J. D. Coulter (1985a) Axonal transport of monoclonal antibodies. Neurosci. Abstr. 11: 1303.

Ritchie, T. C., R. H. Fabian, and J. D. Coulter (1985b) Axonal transport of antibodies to subcellular and protein fractions of rat brain. Brain Res. 343: 252-261.

Ruda, M., and J. D. Coulter (1982) Axonal and transneuronal transport of wheat germ agglutinin demonstrated by immunocytochemistry. Brain Res. 249: 237-246.
Schwab, M. E., and H. Thoenen (1976) Electron microscopic evidence for a transsynaptic migration of tetanus toxin in spinal cord motoneurons: An autoradiographic and morphometric study. Brain Res. 105: 213-227.

Schwab, M. E., and H. Thoenen (1978) Selective binding, uptake and retrograde transport of tetanus toxin by nerve terminals in the rat iris. J. Cell. Biol. 77: 1-13.

Schwab, M. E., and H. Thoenen (1982) Retrograde axonal transport. In Handbook of Neurochemistry, 2nd Ed., Vol. 2, A. Lajtha, ed., pp. 381-404, Plenum, New York.

Schwab, M. E., F. Javoy-Agid, and Y. Agid (1978) Labeled wheat germ agglutinin (WGA) as a new, highly sensitive retrograde tracer in the rat brain hippocampal system. Brain Res. 152: 145-150.

Schwab, M. E., K. Suda, and H. Thoenen (1979) Selective retrograde transsynaptic transfer of a protein, tetanus toxin, subsequent to its retrograde axonal transport. J. Cell Biol. 82: 798-810.

Silverstein, S. C., R. M. Steinman, and Z. A. Cohn (1977) Endocytosis. Annu. Rev. Biochem. 46: 669-722.

Steinman, R. M., I. S. Mellman, W. A. Muller, and Z. A. Cohn (1983) Endocytosis and the recycling of plasma membrane. J. Cell. Biol. 96: $1-27$.

Sternberger, L. A. (1978) The unlabeled antibody peroxidase-antiperoxidase (PAP) method. In Immunocytochemistry, L. Sternberger, ed., pp. 104-169, Wiley, New York.

Thoenen, H., and Barde, Y.-A. (1980) Physiology of nerve growth factor. Physiol. Rev. 60: 1284-1335.

Towbin, H., T. Staehelin, and J. Gordon (1979) Electrophoretic transfer of proteins from polyacrylamide gels to nitrocellulose sheets: Procedure and some applications. Proc. Natl. Acad. Sci. USA 76: 43504354.

Trojanowski, J. Q. (1983) Native and derivatized lectins for in vitro studies of neuronal connectivity and neuronal cell biology. J. Neurosci. Methods 9: 185-204.

van Heyningen, W. E. (1974) Gangliosides as membrane receptors for tetanus toxin, cholera toxin and serotonin. Nature 249: 415-417.

Wan, X. C. S., J. Q. Trojanowski, and J. O. Gonatas (1982) Cholera toxin and wheat germ agglutinin conjugates as neuroanatomical probes: Their uptake and clearance, transganglionic and retrograde transport and sensitivity. Brain Res. 243: 215-224.

Wenthold, R. J., K. K. Skaggs, and R. R. Reale (1984) Retrograde axonal transport of antibodies to synaptic membrane components. Brain Res. 304: 162-165.

Willard, M., W. M. Cowan, and P. R. Vagelos (1974) The polypeptide composition of intra-axonally transported proteins: Evidence of four transport velocities. Proc. Natl. Acad. Sci. USA 71: 2183-2187.

Ziegler, M. G. J. A. Thomas, and D. M. Jacobowitz (1976) Retrograde axonal transport of antibody to dopamine- $\beta$-hydroxylase. Brain Res. 104: 390-395. 